Eur J Clin Chem Clin Biochem 1995; 33:785-789

(c) 1995 Walter de Gruyter \& Co.

Berlin · New York

\title{
Iron Binding Capacity of Trimidox (3,4,5-Trihydroxybenzamidoxime), a New Inhibitor of the Enzyme Ribonucleotide Reductase
}

\author{
By Thomas Szekeres ${ }^{1}$, Elisabeth Vielnascher ${ }^{1}$, Ladislav Novotny ${ }^{2}$, Anna Vachalkova ${ }^{2}$, Monika Fritzer ${ }^{3}$, \\ Gabriele Findenig', Rainer Göbl ${ }^{1}$, Howard L. Elford ${ }^{4}$ and Hans Goldenberg ${ }^{1}$ \\ ${ }^{1}$ Institut für Medizinische Chemie der Universität Wien, Wien, Austria \\ 2 Cancer Research Institute, Slovak Academy of Sciences, Bratislava, Slovak Republic \\ ${ }^{3}$ Klinisches Institut fïr Medizinische und Chemische Laboratoriumsdiagnostik, Universität Wien, Wien, Austria \\ 4 Molecules for Health -Inc., Richmond, Virginia, USA
}

(Received May 9/July 25, 1995)

Dedicated to Professor Dr. E. Kaiser on the occasion of his 70th birthday

Summary: Ribonucleotide reductase is the rate limiting enzyme of deoxynucleoside triphosphate synthesis and is considered to be an excellent target of cancer chemotherapy. Trimidox, a newly synthesized compound, inhibits this enzyme and has in vitro and in vivo antitumour activity. As trimidox was able to upregulate the expression of the transferrin receptor in HL-60 human promyelocytic leukaemia cells, we have now investigated the capability of trimidox to interfere with iron metabolism. We show by photometric and polarographic methods that trimidox is able to form an iron complex. However, its cytotoxic action cannot be circumvented by addition of iron-saturated transferrin or iron-ammonium citrate, indicating that the iron complexing capacity is not responsible for the mechanism of action of this compound. When HL-60, K562 or L1210 leukaemia cells were incubated with the trimidoxiron complex itself, we could observe increases of the $50 \%$ growth inhibitory capacity of the complex in comparison with trimidox alone. We conclude that trimidox is able to form an iron complex, but in contrast to other agents, the anticancer activity cannot be contributed to this effect alone. Further studies will have to elucidate the molecular mechanism of action of this new and promising anticancer agent.

\section{Introduction}

Ribonucleotide reductase ${ }^{1}$ ) is the rate limiting enzyme of de novo deoxyribonucleotide synthesis and shows an increase in activity linked with proliferation and malignant transformation $(1-3)$. It was therefore considered as a target for cancer chemotherapy (4-6). A number of compounds inhibiting this enzyme were synthesized. Only hydroxyurea, a relatively weak inhibitor of ribonucleotide reductase, is clinically used for the treatment of haematological malignancies.

1) Enzymes

Ribonucleotide reductase (EC. 1.17.4.1)

Inosine monophosphate dehydrogenase (IMP-dehydrogenase) (EC 1.1.1.205)

Investigators have synthesized a number of polyhydroxy-substituted benzohydroxamates as inhibitors of ribonucleotide reductase $(7,8)$. Among these compounds, trimidox (3,4,5-trihydroxybenzohydroxamidoxime) (fig. 1) was most effective. It inhibited the growth of various tumour cell lines more effectively than hydroxyurea and

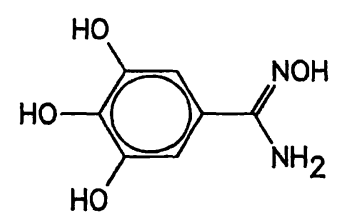

Fig. 1 Structure of trimidox. 
was demonstrated to have in vivo antitumour activity in L12 10 leukaemia bearing mice $(9,10)$. We could also show that trimidox yields synergistic cytotoxic effects with tiazofurin, an inhibitor of IMP-dehydrogenase (11). Trimidox was also able to upregulate the expression of differentiation linked surface markers and the expression of the transferrin receptor (CD 71) in HL-60 human promyelocytic leukaemia cells (11). These results and previous reports suggested that iron chelation plays a role in the mechanism of trimidox action.

The aim of the present study was therefore to investigate whether trimidox is able to form complexes with iron salts and to elucidate the role of trimidox-iron intercalation regarding the biochemical and biological properties of this newly synthesized compound.

\section{Materials and Methods}

Chemicals and supplies

Trimidox was synthesized as described (12). All other chemicals and reagents were commercially available and of highest purity.

\section{Cell culture}

The HL-60 human promyelocytic cell line was a gift from Dr. $R$. C. Gallo (National Cancer Institute, NIH, Bethesda, MD). K562 and L1210 leukaemia cell lines were purchased from ATCC (American Type Culture Collection, Rockville, MD, USA). Cells were grown in RPMI 1640 medium supplemented with heat inactivated fetal calf serum (GIBCO, Grand Island Biological Co., Grand Island, NY, USA), volume fraction 0.1 , supplemented with $1 \%$ penicillin-streptomycin in a humidified atmosphere containing $5 \%$ $\mathrm{CO}_{2}$. Cell counts were determined using the microcellcounter CC108 (Sysmex, Kobe, Japan). Cells growing in logarithmic phase of growth were used for all studies described below.

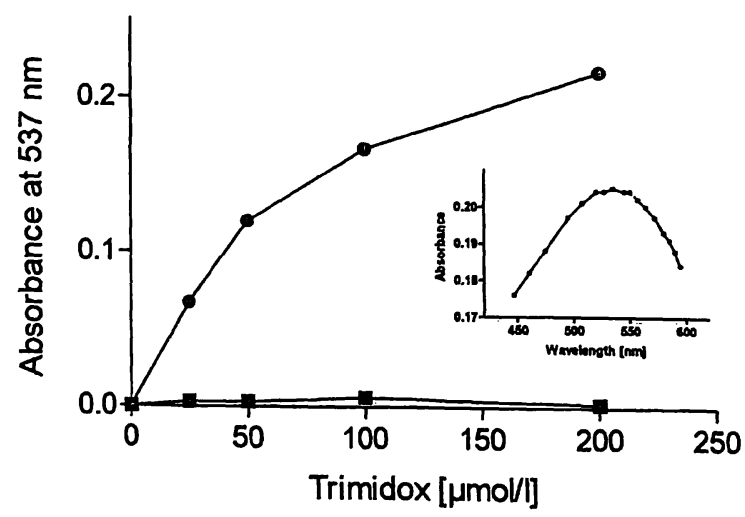

Fig. 2 Various concentrations of trimidox were incubated with $100 \mu \mathrm{mol} / \mathrm{l} \mathrm{Fe}$-ammoniumcitrate (circles) for 2 hours at $37^{\circ} \mathrm{C}$ in an aqueous solution, then absorbance was measured at $537 \mathrm{~nm}$ (maximum absorbance of a mixture of $200 \mu \mathrm{mol} / 1$ trimidox with $100 \mu \mathrm{mol} / / \mathrm{Fe}$-ammoniumcitrate is shown in the insert). After preincubation of $\mathrm{Fe}$-ammoniumcitrate with $200 \mu \mathrm{mol} / \mathrm{l}$ desferroxamin no increase in absorbance could be observed (squares). Data represent means of duplicate determinations. SDs were within $5 \%$.

\section{Growth inhibition assay}

Cells were seeded in $25 \mathrm{~cm}^{2}$ flasks at a cell density of 0.1 $\times 10^{9} / 1$ and incubated with various drug concentrations $(1-100$ $\mu \mathrm{mol} / \mathrm{l}$ ). Cells were counted and $\mathrm{IC}_{50}$ concentrations (drug concentration at $50 \%$ inhibition of cell growth) were determined 4 days later.

$$
\cdot \boldsymbol{i}
$$

\section{Polarographic measurements}

Polarographic measurements were performed using a PA 4 polarographic analyzer, which was interfaced to a two-line $X Y$ 4106 plotter (Laboratorni Pristroje, Praha, The Czech Republic). A dropping mercury electrode with a drop time of $3 \mathrm{~s}$ and a flow rate of $2.27 \mathrm{mg} / \mathrm{s}$ at mercury column height $\mathrm{h}_{\mathrm{Hg}}$ of $81 \mathrm{~cm}$ was used as the indicating electrode. A saturated calomel electrode was used as the reference electrode. A platinum electrode was the auxiliary electrode. All polarographic measurements were carried out at room temperature in a stream of gaseous argon to exclude atmospheric oxygen from the polarographic cell. The $\mathrm{pH}$ was 7.02 .

$\mathrm{FeSO}_{4} \cdot 7 \mathrm{H}_{2} \mathrm{O}$ was used as a source for $\mathrm{Fe}^{2+}$ and $\mathrm{Fe}$-ammonium citrate was the source for $\mathrm{Fe}^{3+}$.

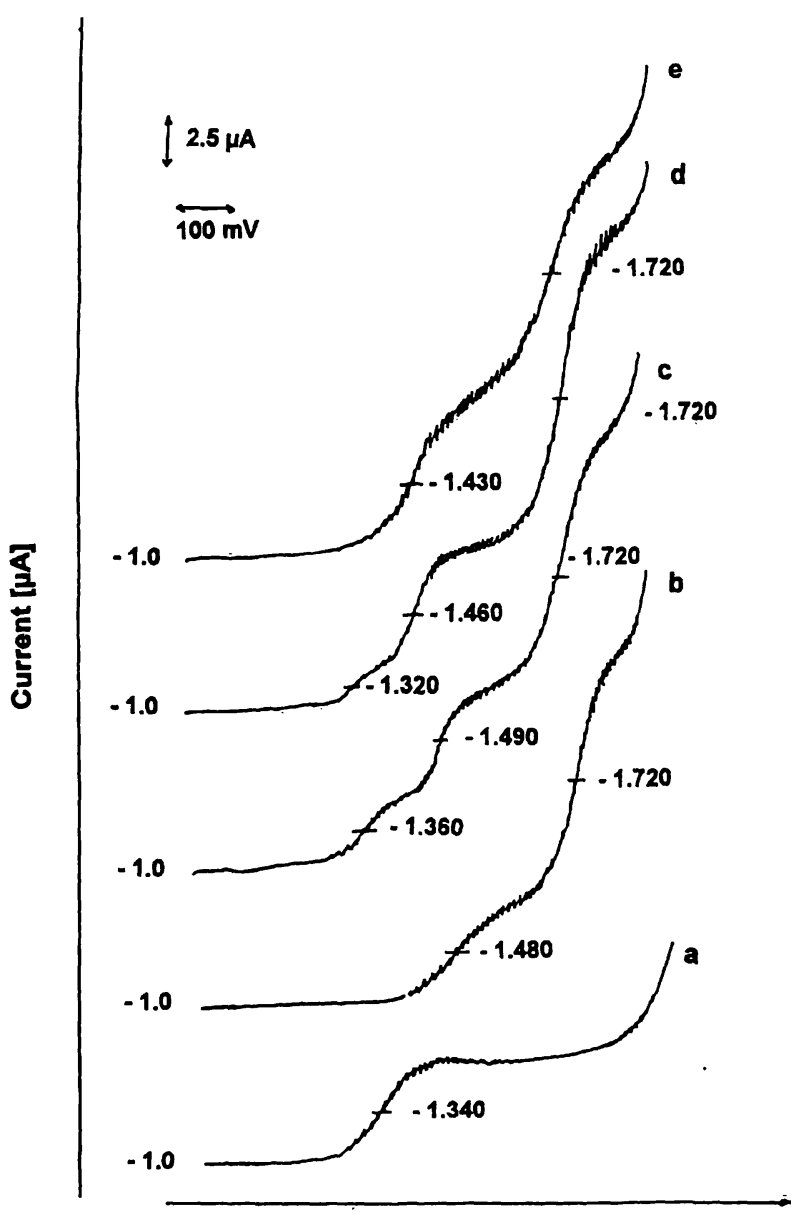

E vs. saturated calomel electrode $[M$

Fig. 3 The polarographic reduction of trimidox in Britton Robinson buffer in the presence of $\mathrm{FeSO}_{4} \cdot 7 \mathrm{H}_{2} \mathrm{O}, \mathrm{pH} 7.02$. a: $1 \mathrm{mmol} / 1 \mathrm{FeSO}_{4}$, b: $1 \mathrm{mmol} / 1$ trimidox, c: mixture of $1 \mathrm{mmol} / \mathrm{l}$ trimidox with $0.25 \mathrm{mmol} / \mathrm{FeSO}_{4}$, $\mathrm{d}$ : mixture of $1 \mathrm{mmol} / \mathrm{h}$ trimidox with $1 \mathrm{mmol} / \mathrm{FeSO}$, e: mixture of $1 \mathrm{mmol} / \mathrm{l}$ trimidox with $2 \mathrm{mmol} / / \mathrm{FeSO}_{4}$. Scan rate $5 \mathrm{mV} / \mathrm{s}$. 


\section{Results}

\section{Formation of a trimidox-iron complex}

\section{Photometric determination}

When trimidox $(25-200 \mu \mathrm{mol} / \mathrm{l})$ was incubated with various concentrations of $\mathrm{Fe}$-ammoniumcitrate $(0-200$ $\mu \mathrm{mol} / \mathrm{l})$ in an aqueous solution, we could observe the formation of a violet colour complex. When $200 \mu \mathrm{mol} / 1$ trimidox were incubated with $100 \mu \mathrm{mol} / 1 \mathrm{Fe}$-ammoniumcitrate in an aqueous solution for 2 hours at $37^{\circ} \mathrm{C}$, the photometric determination showed maximal absorption at $537 \mathrm{~nm}$ (fig. 2, insert).

The absorbance of the violet complex increased with increasing trimidox concentrations (fig. 2, circles), however when $\mathrm{Fe}$-ammoniumcitrate was preincubated with $200 \mu \mathrm{mol} / 1$ desferroxamin for 1 hour prior to incubation with trimidox, the formation of the complex could be inhibited (fig. 2, squares).

\section{Polarographic determination}

a) Polarographic reduction of trimidox in the presence of $\mathrm{Fe}^{2+}$

The equimolar ratio of concentrations trimidox : $\mathrm{FeSO}_{4}$ were $1: 0.25 ; 1: 0.5 ; 1: 1 ; 1: 2$ and $1: 4$. We could observe a one step reduction of $\mathrm{Fe}^{2+}$ in Britton Robinson

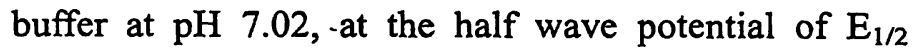
$=-1.340 \mathrm{~V}$ (versus standard calomel electrode). Under the same conditions the reduction of trimidox had two steps $\left(E_{1 / 2}:-1.480\right.$ and $-1.720 \mathrm{~V}$, respectively) (fig. 3). The reduction of trimidox was influenced by the presence of $\mathrm{Fe}^{2+}$-ions as demonstrated by the change in altitude of the polarographic wave of $\mathrm{Fe}^{2+}$, which decreased in a concentration dependent manner with increasing $\mathrm{Fe}^{2+}$ concentrations. These changes were accompanied by the formation of a dark brown colour (equimolar ratio of concentrations trimidox : $\mathrm{FeSO}_{4}$ $=1: 4$ ).

b) Polarographic reduction of trimidox in the presence of $\mathrm{Fe}^{3+}$

The equimolar ratios of concentrations trimidox : $\mathrm{Fe}^{3+}$ were $1: 0.25 ; 1: 0.5 ; 1: 1,1: 1.5$ and $1: 2$. The reduction of $\mathrm{Fe}^{3+}$ at $\mathrm{pH} 7.02$ in Britton Robinson buffer is a one step reduction with a half wave potential of $E_{1 / 2}$ : $-0.490 \mathrm{~V}$ (versus standard calomel electrode). The reduction of trimidox could be significantly influenced by the presence of $\mathrm{Fe}^{3+}$ ions as shown in figure 4. The first polarographic wave of trimidox increased markedly even at low $\mathrm{Fe}^{3+}$ concentrations (equimolar ratio trimidox $\left.: \mathrm{Fe}^{3+}=1: 0.25\right)$ and its $\mathrm{E}_{1 / 2}$ shifts significantly about $60 \mathrm{mV}$ to more positive values. The wave generated by $\mathrm{Fe}^{3+}$ alone decreases with increasing trimidox concentrations whereas an increase of the wave caused by trimidox could be observed (fig. 4 curve e, f). With increasing iron concentration the development of a dark violet colour could be observed.

\section{Effect of iron on in vitro growth inhibitory capacity of trimidox}

When HL-60 promyelocytic leukaemia cells were incubated with various concentrations of trimidox, addition of iron $(50 \mu \mathrm{mol} / \mathrm{l} \mathrm{Fe}$-ammoniumcitrate) did not significantly alter the $\mathrm{IC}_{50}(50 \%$ inhibitory capacity) of trimidox (fig. 5).

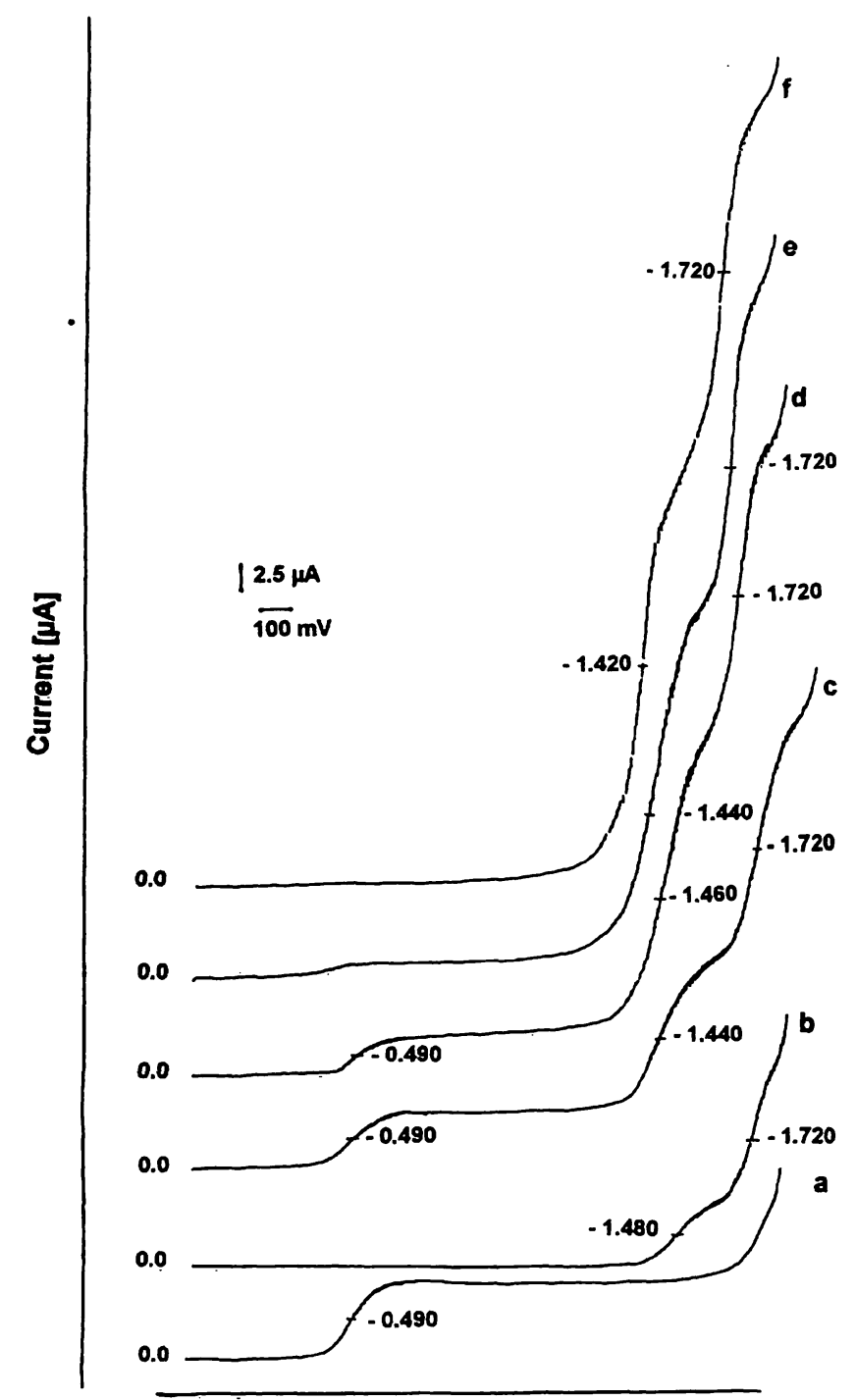

E vs. saturated calomel electrode [M]

Fig. 4 The polarographic reduction of trimidox in Britton Robinson buffer in the presence of $\mathrm{Fe}^{3+}$, $\mathrm{pH} \mathrm{7.02}$. a: $1 \mathrm{mmol} / 1 \mathrm{Fe}^{3+}$,

b: $1 \mathrm{mmol} / \mathrm{h}$ trimidox, c: mixture of $1 \mathrm{mmol} / \mathrm{l}$ trimidox with $0.25 \mathrm{mmol} / 1 \mathrm{Fe}^{3+}$, d: mixture of $1 \mathrm{mmol} / \mathrm{trimidox}$ with $0.5 \mathrm{mmol} / \mathrm{Fe}^{3+}$, e: mixture of $1 \mathrm{mmol} / /$ trimidox with $1.5 \mathrm{mmol} / 1 \mathrm{Fe}^{3+}$, f: mixture of $1 \mathrm{mmol} / \mathrm{l}$ trimidox with $2 \mathrm{mmol} / 1 \mathrm{Fe}^{3+}$. Scan rate $5 \mathrm{mV} / \mathrm{s}$. 
Effect of iron-saturated transferrin on the growth inhibitory action of trimidox

When HL-60 cells were incubated with various concentrations of trimidox, addition of $20 \mathrm{~g} / 1 \mathrm{Fe}$-saturated transferrin slightly increased the $\mathrm{IC}_{50}$ of trimidox (from 10.5 to $14 \mu \mathrm{mol} / \mathrm{l}$ ), however the action of trimidox could not be circumvented (fig. 6).

\section{Cytotoxic effects of the iron-trimidox complex in leukaemia cell lines}

Various concentrations of trimidox were incubated with $40 \mu \mathrm{mol} / \mathrm{l} \mathrm{Fe}$-ammoniumcitrate $20-30$ minutes prior to incubation of different cell lines to allow the formation of the iron-trimidox complex. The human HL-60 and K562 leukaemia cell lines and the mouse L1210 leukaemia cell line were then incubated with trimidox or with the iron-trimidox complex. On day 4 cell numbers were determined. In HL-60 cells, both trimidox and the Fetrimidox complex yielded similar $\mathrm{IC}_{50} \mathrm{~S}$ (data not shown). In $\mathrm{K} 562$ cells trimidox yielded an $\mathrm{IC}_{50}$ of 10 $\mu \mathrm{mol} / 1$ and the complex had an $\mathrm{IC}_{50}$ of $14 \mu \mathrm{mol} / 1$ under the same conditions. In L1210 cells trimidox showed an $\mathrm{IC}_{50}$ of 6 and the iron-trimidox complex an $\mathrm{IC}_{50}$ of 16 $\mu \mathrm{mol} / 1$, respectively (fig. 7 ).

\section{Discussion}

Ribonucleotide reductase is the rate limiting enzyme of de novo deoxynucleoside triphosphate (dNTP) synthesis and was therefore considered to be an excellent target of cancer chemotherapy $(1,3,5)$. We have previously described the cytotoxic, differentiating and in vivo ef-

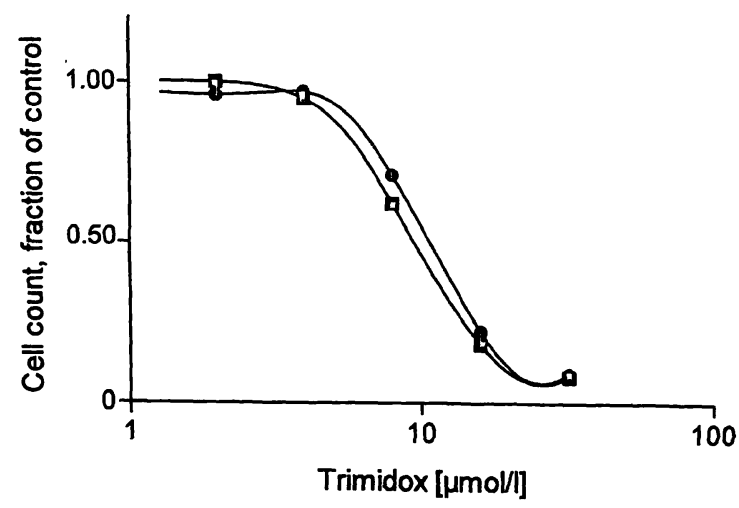

Fig. 5 HL-60 human promyelocytic leukaemia cells were seeded at a density of $0.1 \times 10^{9} / 1$ with various concentrations of trimidox. Fifty $\mu \mathrm{mol} / \mathrm{l} \mathrm{Fe}$-ammoniumcitrate was added at the time of seeding (squares); untreated control cell numbers are plotted as circles. At day 4 cell number was determined as described in the methods. Data represent means of duplicate determinations of one representative experiment (out of 3 ). SDs were within $5 \%$. fects of a newly synthesized compond, trimidox (11). We could show that trimidox inhibits ribonucleotide reductase activity and demonstrated that trimidox is able to upregulate transferrin receptor expression (CD 71) in human promyelocytic HL-60 cells $(10,11)$. Combination of trimidox with tiazofurin, an inhibitor of IMP dehydrogenase, caused synergistic cytotoxic and differentiation effects in HL-60 cells (11). Our results indicate trimidox to be a promising agent for the treatment of human malignancies, however its mechanism of enzyme inhibition has not yet been elucidated (11). The aim of the present study was to investigate whether the inhibition of the enzyme is caused by formation of an irontrimidox complex.

Ribonucleotide reductase consists of two distinct subunits (R1, R2) which are required for enzymatic activity. Inhibition of the enzyme can be caused by scavenging of a free tyrosyl radical or iron deprivation, as iron is a cofactor for generation and stabilization of the free tyrosyl radical (5). We could now clearly demonstrate and prove by photometric and polarographic determinations that trimidox is capable of forming a complex with iron. However addition of an iron salt to the culture medium did not significantly alter the growth inhibitory effect of trimidox in HL-60 cells, indicating that the iron binding property is not the main mechanism of action of the agent. We could also show that trimidox action was only slightly compromised by addition of iron-saturated transferrin.

When various cell lines were incubated with the irontrimidox complex itself, increases of the $\mathrm{IC}_{50}$ s were observed when compared with the $50 \%$ growth inhibitory concentration of the pure compound in L1210 and K562 leukaemia cells. However, the cytotoxic effect of trimi-

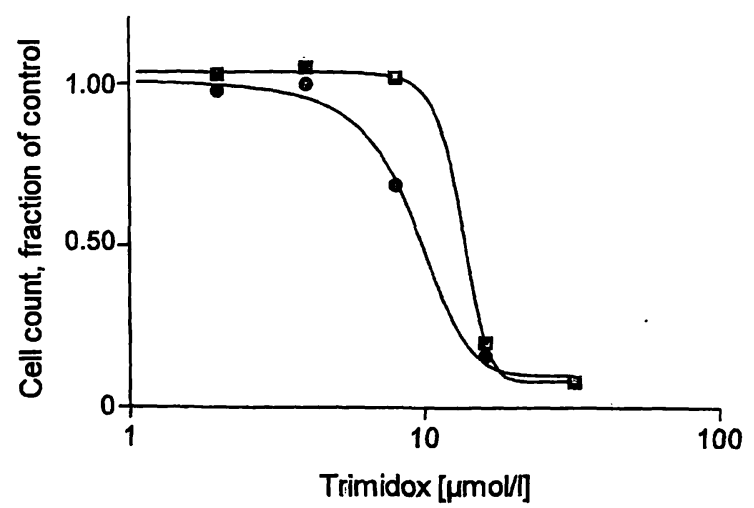

Fig. 6 HL-60 human promyelocytic leukaemia cells were seeded at a density of $0.1 \times 10^{9} / 1$ with various concentrations of trimidox. Fe-transferrin treated (squares) cells were incubated with $20 \mathrm{~g} / 1$ iron saturated transferrin at day 0 ; untreated control cell numbers are plotted as circles. At day 4 cell number was determined as described in the methods. Data represent means of duplicate determinations of one representative experiment (out of 3). SDs were within $5 \%$. 


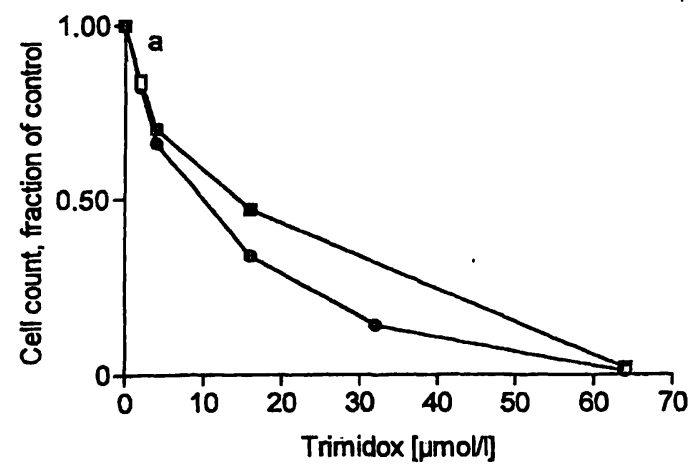

Fig. 7 Human K562 leukaemia cells (a) and mouse leukaemia L1210 cells (b) were seeded at a concentration of $0.1 \times 10^{9} / 1$ with various concentrations of trimidox or trimidox-Fe-ammoniumcitrate-complex. For preparation of the complex $40 \mu \mathrm{mol} / \mathrm{l} \mathrm{Fe}$-ammo-

dox could not be circumvented completely as the $\mathrm{IC}_{50}$ concentrations (14 and $16 \mu \mathrm{mol} / \mathrm{l}$ in $\mathrm{K} 562$ and $\mathrm{L} 1210$ cells respectively) remained relatively low. Although trimidox is capable of forming a stable complex with iron, the mechanism of action of trimidox ought to be due to other chemical properties as well. It might be caused by the recently demonstrated free radical scavenging capacity of trimidox (13) or by other enzyme inhibitory effects. Further ongoing studies will have to

\section{References}

1. Weber G. Enzymology of cancer cells. New Engl J Med 1977; 296:486-83.

2. Takeda E, Weber G. Role of ribonucleotide reductase in the expression of the neoplastic program. Life Sci 1981; 28:1007-14.

3. Elford HL, Freese M, Passamani M, Morris HP. Ribonucleotide reductase and cell proliferation. J Biol Chem 1970; 245:5228-33.

4. Cory JG, Carter GL. Drug action on ribonucleotide reductase. Advan Enzyme Regul 1985; 24:385-401.

5. Cory JG. Ribonucleotide reductase as a chemotherapeutic target. Advan Enzyme Regul 1988; 27:437-55.

6. Elford HL, van'T Riet B, Wampler GL, Lin AL, Elford RM. Regulation of ribonucleotide reductase in mammalian cells by chemotherapeutic agents. Advan Enzyme Regul 1981; 19:151-68.

7. Elford HL, Wampler GL, Van'T Riet B. New ribonucleotide reductase inhibitors with antineoplastic activity. Cancer Res 1979; 39:844-51.

8. Van'T Riet B, Kier LB, Elford HL. A structure activity relationship analysis of benzohydroxamic acid inhibitors of ribonucleotide reductase. J Pharm Sci 1980; 69:856-7.

9. Szekeres T, Gharehbaghi K, Fritzer M, Woody M, Srivastava $A$, van'T Riet B, et al. Biochemical and antitumor activity of trimidox, a new inhibitor of ribonucleotide reductase. Cancer Chemother Pharmacol 1994; 34:63-6.

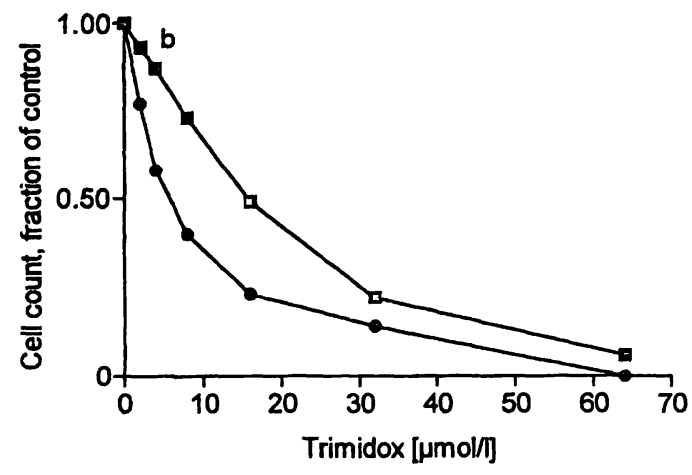

niumcitrate (squares) was mixed with various concentrations of trimidox and incubated 30 minutes prior to use, at room temperature. Untreated control cell numbers are plotted as circles.

elucidate the exact mechanism of action of this promising anticancer agent.

\section{Acknowledgements}

This work was supported by the "Anton Dreher Gedächtnisschenkung für Medizinische Forschung", the "Fonds zur Förderung der wissenschaftlichen Forschung des Bürgermeisters der Bundeshauptstadt Wien", a grant of the "Jubiläumsfonds der österr. Nationalbank, Grant No.: 5267" and by a grant of the Slovak Grant Agency Nr. 1331/94.
10. Szekeres T, Fritzer M, Schön HJ, Findenig G, Lhotka C. Synergistische zytotoxische Effekte von Kombinationschemotherapie durch gleichzeitige Hemmung von de novo und salvage Stoffwechselwegen. Wien Klin Wochenschrift 1994; 14:459-63.

11. Szekeres T, Fritzer M, Strobl H, Gharehbaghi K, Findenig G, Elford HL, et al. Synergistic growth inhibitory and differentiating effects of trimidox and tiazofurin in human promyelocytic leukemia HL-60 cells. Blood 1994; 84:4316-21.

12. van'T Riet B, Wampler GL, Elford HL. Synthesis of hydroxyand amino-substituted benzohydroxamic acids: inhibition of ribonucleotide reductase and antitumor activity. J Med Chem $1979 ; 22: 589-92$.

13. Elford HL, Van'T Riet B, Mikhail EA, Zweier JL. Free radical scavengers trimidox and didox protect against cardiac toxicity and improve antitumor activity of anthracyclines [abstract]. Proc Am Ass Cancer Res 1995; 36:296.

Univ. Doz. Dr. Thomas Szekeres Institut für Medizinische Chemie der Universität Wien A-1090 Wien Währingerstraße 10 Austria 
